\title{
3 Research Square

\section{Propagation in Vitro and Experimental Field \\ Cultivation ex Situ of Pulsatilla Turczaninovii Kryl. et Serg. (Ranunculaceae)}

Ewa Joanna Hanus-Fajerska ( $\nabla$ e.hanus-fajerska@urk.edu.pl )

University of Agriculture in Krakow: Uniwersytet Rolniczy im Hugona Kollataja w Krakowie https://orcid.org/0000-0003-0566-0641

Dawid Kocot

University of Agriculture in Krakow: Uniwersytet Rolniczy im Hugona Kollataja w Krakowie

Aleksandra Koźmińska

University of Agriculture in Krakow: Uniwersytet Rolniczy im Hugona Kollataja w Krakowie

Alina Wiszniewska

University of Agriculture in Krakow: Uniwersytet Rolniczy im Hugona Kollataja w Krakowie

\section{Ewa Muszyńska}

Warsaw University of Life Sciences: Szkola Glowna Gospodarstwa Wiejskiego w Warszawie

\section{Research Article}

Keywords: adventitious roots, biomarkers, ex situ conservation, tissue culture, Siberian Pasque Flower

Posted Date: March 22nd, 2021

DOl: https://doi.org/10.21203/rs.3.rs-325141/v1

License: (c) (1) This work is licensed under a Creative Commons Attribution 4.0 International License. Read Full License

Version of Record: A version of this preprint was published at Plant Cell, Tissue and Organ Culture (PCTOC) on July 15th, 2021. See the published version at https://doi.org/10.1007/s11240-021-02140-0. 


\section{Abstract}

Pulsatilla turczaninovii is an important medicinal plant and a material also appreciated by gardeners for its high ornamental value. In this study we assessed the efficiency of reproduction under in vitro conditions of this important representative of the world flora. First, the germination percentage and the following plant development during three growing seasons were assessed, then we tested the possibilities of multiplication by in vitro culture methods. Our study provided new insight on biochemical background of generating adventitious roots in Pulsatilla considered difficult-to-rooting. The germination percentage of studied population reached about $55 \%$. The highest multiplication coefficient of microrosettes in tissue culture, amounting to 5.17, was achieved using modified MS medium supplemented with $2.5 \mathrm{mg} \mathrm{L}^{-1}$ 2iP and $1 \mathrm{mg} \mathrm{L}^{-1} \mathrm{IAA}$. We proved that in comparison with standard auxin-supplemented rooting medium, the treatment with addition of $1.0 \mathrm{mg} \mathrm{L}^{-1}$ ethylene precursor ACC elevated adventitious rooting by about $20 \%$. The biochemical analyses revealed that total content of soluble sugars was the most impactful biomarker of adventitious rhizogenesis in studied species. Concentration of sugars was positively correlated with rooting efficiency, while the level of phenolic compounds was positively correlated with the root length and their number regenerated per single rosette.

\section{Introduction}

Representatives of the Ranunculaceae family are highly valued for their multiple usefulness for humans, and due to long-term growth and relative longevity of populations they are of great importance in the natural environment (Antoń and Kamińska 2015; da Silva et al. 2012; Hao et al. 2015; Jiang et al. 2017; Deng et al. 2019). In addition to high value in nature (Bochenková et al. 2012, 2015), Pulsatilla species have medicinal properties (Danova et al. 2009; Hao et al. 2015; Lin et al. 2011; Łaska et al. 2019; Łaska and Sienkiewicz 2019). Moreover, many colorful cultivars are used in green areas because Pulsatilla flowers, profusely secreting nectar, are attractive to pollinators (Weryszko-Chmielewska et al. 2017). Thus, not only for purely cognitive, but also for application reasons, Sramkó with coworkers (2019) have reconstructed the evolutionary history of a genus Pulsatilla belonging to Ranunculaceae, subfamily Ranunculoideae, and tribe Anemonae (Tamura 1993, Milinarec et al. 2016), which include mainly Asiatic species, such as $P$. turczaninovii from subsection Albanae.

Pulsatilla is a perennial that grows in different habitats on a fairly poor soil, such as subalpine or alpine natural grasslands steppes, xerothermic grasslands or so called meadow steppes which are currently prone to degradation. Wherever it grow, a continuous habitat fragmentation takes place (Di Musciano et al. 2018; Ermakow et al. 2014; Kaligaričet et al. 2006; Stanisci et al. 2005). Moreover, every single microhabitat might become covered with dense, high vegetation or dense moss layer (Gantuya et al. 2019; Xu et al. 2020). The specimens of $P$. turczaninovii predominantly occur in vegetation-free gaps, like other Pulsatilla species which cannot grow in the shade. This hemicryptophyte grows well in fully illuminated locations where vegetation is sparse, such as clearing in grasslands on slopes of southern exposition (Zainelabdeen et al. 2020). Due to the above, this species is endangered in the natural environment. 
Different species of pasque flower interbreed in horticulture but $P$. turczaninovii is rarely found in gardens (Radziul 2015). However, due to value for pollinating insects it is worth spreading more widely. It is justified to introduce this species to in vitro cultures, which are reliable source of plants for gardening but applied primarily for protection purposes. The constant progress in the technology of micropropagation enables faster and effective obtaining of balanced vegetative offspring in comparison to the results of classic reproduction methods (Hanus-Fajerska et al. 2019; Muszyńska et al. 2018; Philips and Garda 2019). Techniques of culturing tissues and organs in vitro allow regenerating numerous micro-plantlets under controlled aseptic conditions, from one donor plant or from its fragment. The applicability of tissue culture protocols for about thirty known Pulsatilla species has not been comprehensively studied to date, although several important contributions presenting in vitro culture protocols of some European (Priede and Kḷavina 2011) and Asiatic (Jin et al. 2007; Lin et al. 2011) species were published. Study of Priede and Klavina (2011) revealed that Pulsatilla species are difficult-to-root, and usually multi-step protocol is required for root development. Rooting difficulties are related to fluctuations and impairments in the contents and activity of some biochemical parameters considered as markers of rhizogenesis. These are in particular the content of phenolic compounds, carbohydrates and the activity of antioxidant enzyme, peroxidase (POD), that change during successive stages of rooting (Günes 2000; Denaxa et al. 2012, 2020). Treatment with plant growth regulators, especially with exogenous auxins, is crucial for successful development of adventitious roots (Priede and Klavin,a 2011, Park et al. 2017). Rooting is also affected by ethylene fluctuations, however whether the effect may be stimulatory or inhibitory it depends on the species and other physicochemical stimuli (Xu et al. 2017, Fattorini et al. 2018). To our knowledge, biochemical background of adventitious rooting in representatives of Pulsatilla genus still remains unclear.

Here we present the comprehensive study on Pulsatilla turczaninovii, in which we aimed at (i) evaluating germination of seeds in ex situ conditions followed by 3-seasons observation and characterization of the obtained plants in the field conditions, and (ii) elaborating the successive steps of in vitro culture, that is culture initiation, micro-rosettes regeneration and rooting. We tested formation of roots under auxin and ethylene precursor (1-aminocyclopropane-1-carboxylic acid (ACC)) treatments, applied alone or in a combination. Additionally, to make an insight into the process of rooting we determined and correlated rooting parameters with fluctuations in the level of biochemical markers related to rooting efficiency: phenolic compounds, total soluble sugars and POD activity. Simultaneously, we assessed the growth performance of the acquired $P$. turczaninovii plants in order to effectively cultivate them in the Polish climatic conditions with the intention of creating an ex situ collection, which could partially contribute to the Pulsatilla protection program.

\section{Materials And Methods}

The seeding material In the present study the research material was Pulsatilla turczaninovii Kryl. et Serg. (Ranunculaceae). The initial material, i.e. fruits, was collected from a natural population growing in Siberia at a site located in Sludian Region in the Irkutsk Oblast, Russia with the geographical coordinates 51.7 N, 103.7 E. Population from which fruit samples were collected close to the time of its dispersal grew 
on the grassy shores in the region of Lake Baikal (Fig. 1) which is located inside the Eurasian continent. The formal verification of plant material was conducted by dr hab. Anna Pacyna, from W. Szafer Institute of Botany, Polish Academy of Sciences, Kraków, Poland, for which the authors express great gratitude. About 300 maturing achenes were carefully collected by hand in mid-July 2012, with only a few of them from given acheneceum that is the fruiting shoot of the plant. Seed cleaning was performed at the site, by hand removal of small distorted fruits and stem debris or tiny leaf fragments. After this pre-screening, the purified samples were stored in paper envelopes at $20^{\circ} \mathrm{C}$. Elongated pistil styles were manually removed from achenes prior to seeding.

Generative propagation and plant cultivation ex situ From the harvested material 35 achenes were randomly selected. The experiment begun on March 15, 2013. Seeds were sown at a constant density, one for each square centimeter in a substrate consisting of peat, sand and perlite $(1: 1: 1)$. The germination percentage of seeds was assessed after 4 weeks. The obtained plants were transplanted into pots and cultivated to obtain mature individuals. Sixteen of them was cultivated in an unheated greenhouse and the same number in the ground (pitted in pots). In second year, after wintering, the plants were planted out of the pots and transferred to the ground in the rock garden, located in Pyrzowice (south Poland, $50.5 \mathrm{~N}, 19.1 \mathrm{E}$ ). The material used to build the rock garden was limestone and sandstone. The garden was located in the frost resistance zone $6 \mathrm{~b}$, which means that the average below-zero temperature in winter ranged from -20.5 to $-17.8^{\circ} \mathrm{C}$, and during the vegetation period from 15 to $35^{\circ} \mathrm{C}$. The average annual rainfall is $600-700 \mathrm{~mm} /$ year. The development of plants growing in the garden was monitored during next two seasons.

Initiation of in vitro culture Fruits (covered with simple, silky hairs) were surface sterilized by immersion in $70 \%$ ethanol for 2 minutes, followed by immersion for $4 \mathrm{~min}$. in $0.1 \%(\mathrm{w} / \mathrm{v})$ mercuric chloride $\left(\mathrm{HgCl}_{2}\right)$ solution containing 3 drops of Tween-80, and then thoroughly rinsed four times with autoclaved distilled water. Aseptic achenes were placed on medium described as S0 containing $1 / 4$ concentration of MS salts (Murashige and Skoog 1962) without phytohormones, supplemented with vitamins: $0.1 \mathrm{~g} \mathrm{~L}^{-1}$ myoinositol, $0.5 \mathrm{mg} \mathrm{L}^{-1}$ tiamine, $0.5 \mathrm{mg} \mathrm{L}^{-1}$ pyridoxine, $0.5 \mathrm{mg} \mathrm{L}^{-1}$ nicotinic acid, as well as $20 \mathrm{~g} \mathrm{~L}^{-1}$ sucrose, $0.6 \mathrm{~g} \mathrm{~L}^{-1}$ activated charcoal, and $5.0 \mathrm{~g} \mathrm{~L}^{-1}$ agar (Difco Laboratories Inc. UK). Achenes with gentle incised pericarp, after surface decontamination, were placed in $100 \mathrm{ml}$ Erlenmeyer flasks filled with $10 \mathrm{ml}$ of medium. The experiment consisted of 10 flasks with 10 achenes per flasks. Germination was carried out in a growth chamber illuminated with white light during the day, using of $16 / 8$ photoperiod and a temperature of $22 / 14^{\circ} \mathrm{C}$ (day/night). After 4 weeks the number of aseptic seedlings obtained under in vitro conditions was assessed.

In vitro vegetative stage - plant material and culture conditions Aseptic seedlings were primary explants for micropropagation. The 15-20 mm long their apical parts were placed vertically on the medium. For the micropropagation experiment the explants were taken from stabilized culture. Two basal media were tested: MS medium (Murashige and Skoog 1962) and Woody Plant Medium (WPM) (Lloyd and McCown 
1980), both supplemented with $2.0 \mathrm{mg} \mathrm{L}^{-1}$ glycine, $0.1 \mathrm{mg} \mathrm{L}^{-1}$ tiamine, $0.5 \mathrm{mg} \mathrm{L}^{-1}$ pyridoxine, $0.5 \mathrm{mg} \mathrm{L}^{-}$ 1 nicotinic acid, $0.1 \mathrm{~g} \mathrm{~L}^{-1}$ myo-inositol, $20 \mathrm{~g} \mathrm{~L}^{-1}$ sucrose, $0.5 \mathrm{~g} \mathrm{~L}^{-1} \mathrm{PVP}, 0.65 \mathrm{~g} \mathrm{~L}^{-1}$ calcium gluconate.

Experiment was divided into two stages, the first (S1) and second (S2), which lasted 4 and 6 weeks, respectively. Media in the two stages differed in relation to plant growth regulators concentration. In S1 two media were tested: S1-1: MS + $0.5 \mathrm{mg} \mathrm{L}^{-1} \mathrm{N6}$-[2-isopentyl]adenine (2iP), $0.1 \mathrm{mg} \mathrm{L}^{-1}$ indole-3-acetic acid (IAA); and S1-2: WPM + $2.5 \mathrm{mg} \mathrm{L}^{-1} 2 \mathrm{iP}$ and $1 \mathrm{mg} \mathrm{L}^{-1} 1$-naphthaleneacetic acid (NAA). In the second four media formulations were evaluated: S2-1: $M S+1.0 \mathrm{mg} \mathrm{L}^{-1} 2 \mathrm{iP}+0.2 \mathrm{mg} \mathrm{L}^{-1}$ IAA; S2-2: WPM + 1.0 $\mathrm{mg} \mathrm{L}^{-1} 2 \mathrm{iP}+0.2 \mathrm{mg} \mathrm{L}^{-1} \mathrm{IAA} ; \mathrm{S} 2-3: \mathrm{MS}+2.5 \mathrm{mg} \mathrm{L}^{-1} 2 \mathrm{iP}+1 \mathrm{mg} \mathrm{L}^{-1} \mathrm{IAA} ; \mathrm{S} 2-4: \mathrm{WPM}+2.5 \mathrm{mg} \mathrm{L}^{-1} 2 \mathrm{iP}+1$ $\mathrm{mg} \mathrm{L}^{-1}$ IAA.

Medium $\mathrm{pH}$ was adjusted to 5.8 prior to solidification with $8.0 \mathrm{~g} \mathrm{~L}^{-1}$ agar and autoclaving for $20 \mathrm{~min}$ at $0.1 \mathrm{MPa}$. Explants were cultured in $250 \mathrm{ml}$ Erlenmeyer flasks containing $50 \mathrm{ml}$ of the respective medium, using at least four explants for flask. The cultures were kept in a vegetation chamber with $70 \%$ air humidity, $22^{\circ} \mathrm{C}$ day $/ 18^{\circ} \mathrm{C}$ night temperature, with a $16 / 8 \mathrm{~h}$ photoperiod. The light source was cool white fluorescent lamps with a photon flux density of $80 \mu \mathrm{mol} \mathrm{m} \mathrm{m}^{-2} \mathrm{~s}^{-1}$. The experiment was carried out in six replications, and it was repeated twice. Biometric measurements of explants were carried out. After measuring the fresh weight (FW), a part of the fresh material was dried in the oven for 24 hours at $105^{\circ} \mathrm{C}$, until constant weight in order to obtain dry weight (DW). FW and DW data were then used to calculate the water content percentage. Multiplication coefficient (MC) was calculated as the number of newly formed rosettes from one initial explant. The length of microrosettes was measured as well as the number of leaves per microrosette was counted.

Rooting step The starting material was a stabilized culture of $P$. turczaninovii cultivated on modified S1-1 medium from the in vitro vegetative stage. The plant material was cut to approx. 20-mm long explants (microrosettes), which were transferred to rooting induction media described as S3: S3-1- MS medium without phytohormones (control treatment), S3-2-MS + $1.0 \mathrm{mg} \mathrm{L}^{-1}$ indole-3-butyric acid (IBA); S3-3 -MS + $1.0 \mathrm{mg} \mathrm{L}^{-1}$ ACC; and S3-4 - MS $+1.0 \mathrm{mg} \mathrm{L}^{-1} \mathrm{IBA}+1.0 \mathrm{mg} \mathrm{L}^{-1}$ ACC. For each treatment (for each medium variant) fifteen culture flasks with three rosettes were prepared. Induction phase took 7 days and afterwards microplants were transferred to a hormone-free medium (S3-1) for 6 weeks for root elongation. Regenerated roots were counted and measured for each individual microrosette, the rooting efficiency was assessed on the basis of percentage of rooted plantlets. Data were collected from 45 plantlets from each medium variant.

Biochemical analyses Biochemical analyses (TPC, TSS and POD) were conducted at the beginning of rooting induction phase (day 0 referred to as a control) and at 2 nd and 7 th day of rooting induction phase in microrosettes.

Total phenolic compounds (TPC) determination. The content of total phenolic compounds was determined in $80 \%(\mathrm{v} / \mathrm{v})$ methanol extract of $100 \mathrm{mg}$ of fresh plant material and quantified as described in Blainski et al (2013) by a reaction with the Folin-Ciocalteu reagent. The extracts were mixed with the 
reagent and sodium carbonate and left in the dark for $90 \mathrm{~min}$. Absorbance was recorded at $765 \mathrm{~nm}$, and the results were expressed in equivalents of gallic acid used as a standard ( $\mathrm{mg}$ eq GA g ${ }^{-1} \mathrm{FW}$ ).

Total soluble sugars (TSS). The soluble sugars content was quantified according to the method described by Powel (1973). $100 \mathrm{mg}$ of fresh material was mixed with $80 \%$ methanol on orbital shaker overnight, $100 \mu \mathrm{L}$ of the extracts was mixed with $0.5 \mathrm{~mL}$ of $5 \%$ phenol and $2.5 \mathrm{~mL}$ of concentrated sulfuric acid before absorbance reading were taken at $490 \mathrm{~nm}$. TSS contents were expressed as mg equivalent of glucose per gram FW.

Peroxidase (POD) activity. POD activity was measured according to the method described by Putter (1974) with minor modifications. $100 \mathrm{mg}$ of plant material was homogenized in $5 \mathrm{~mL}$ ice-cold phosphate buffer $(\mathrm{pH}=6.2)$. The extracts were centrifuged at $4^{\circ} \mathrm{C}$ for $15 \mathrm{~min}$. at $4800 \mathrm{~g}$ and the supernatants were analyzed. For analyses of POD activity p-phenyldiamine was used as enzyme substrate, which is oxidized by POD to phenazine. $1 \mathrm{~mL}$ of extract was mixed with $0.1 \mathrm{~mL}$ of phosphate buffer. $0.1 \mathrm{~mL}$ of $1 \%$ solution of p-phenyldiamine was mixed with $0.1 \mathrm{~mL}$ of $0.1 \% \mathrm{H}_{2} \mathrm{O}_{2}$. The absorbance of colored reaction product was measured at $485 \mathrm{~nm}$. One unit of POD activity corresponds to an absorbance increase of 0.1 .

Statistical analysis Experiments were organized according to a randomized design. In the methodology, the exact number of repetitions is given for each stage of in vitro experiments. During biochemical analyses the mean and standard deviation ware calculated from five replicates per medium for each set day. Shapiro-Wilk test was used to check for normality assumption. The results were subjected to a statistical analysis using the ANOVA module in STATISTICA ver. 13.0 software (StatSoft Inc.). A post-hoc comparisons were made with Tukey test, and the differences between means were assessed at $P<0.05$. Rooting parameters and the content of biochemical markers (TPC, TSS, POD activity) were correlated using correlation matrix module. Correlation coefficients $<-0.7$ and $>0.7$ were considered significant.

\section{Results}

An initial experiment - generative Pulsatilla turczaninovii propagation and plant cultivation

Ex situ germination of $P$. turczaninovii seeds taken from natural site (Fig. 1) was evaluated. The average germination after 4 weeks was $55.4 \%$. The number of seedlings obtained in individual replications differed slightly. Obtained seedlings differed in the number of proper leaves produced, ranging from two to six developed during 16 weeks of cultivation. $45 \%$ of seedlings assessed had three leaves, $32 \%$ produced six, $14 \%$ four and $9 \%$ only one developed leaf what shows that in the first year they developed slowly. After 16 weeks plantlets were transferred into individual pots. The plants were divided into two groups, one pitted winter in the ground, and the other part in an unheated greenhouse. The greenhouse cultivated plants developed longer leaves. In the following season, plants continued to grow (83.3\%) and $16.7 \%$ of them developed 1-2 flowers. In the third season, all plants entered the generative phase, producing from a few to a dozen flowers and numerous shoots creating large clumps. Another wintering turned out to be troublesome, as plants with the largest (3.6\%) biomass were partially rotting. The results 
collected during three seasons are presented in Table 1. Figure 2 presents structural elements of the mature plant.

Table 1

Field growth performance of Pulsatilla turczaninovii during three seasons of ex situ cultivation

$\begin{array}{llll}\begin{array}{l}\text { Growing } \\ \text { season }\end{array} & \text { First season Second season Third season }\end{array}$

Observations The seedlings transplanted into pots were growing in containers throughout the season. Plants developed slowly and formed 2-6 leaves. They were divided into groups (1) left in an unheated greenhouse (2) pitted in the ground. Differences were ascertained between groups in terms of leaf length (from $40.5 \mathrm{~mm}$ to $60.7 \mathrm{~mm}$ ). Plants wintering under cover were characterized by long leaves (on average by $11.5 \mathrm{~mm}$ ) .
All plants survived the winter. In the spring their intensive development took place. In this season $83,3 \%$ plants produced rosette consisting of a dozen 10-15 cm long leaves, whereas $16.7 \%$ of material entered the generative phase and produced one or two flowers.

In the third
vegetation
period the
plants grew
rapidly. All of
them entered
the generative
phase,
developing
large clumps
consisting of a
dozen blooming
shoots and
numerous
leaves per
rosette.

The

appearance

of the plants

\section{Culture initiation, in vitro vegetative propagation and rooting of micro-rosettes}

Germination under in vitro conditions was similar to the results obtained previously during sowing seeds directly into the substrate, as $47.9 \%$ of seeds germinated on the on $1 / 4$ MS medium (Fig. 3). The appearance of the microrosettes used in the experiment is shown in Fig. 4A. During micropropagation experiment, some rosettes regenerated on the WPM medium (S1-2) were in poor condition, with anthocyanin discoloration, and most of these dried up over time (Fig. 4B). In turn, the rosettes developed on the MS (S1-2) were properly colored, they multiplied well and maintained a healthy appearance (Fig. 4C). The average FW of shoots obtained on the modified S1-1 medium ( $0.48 \mathrm{~g})$, and was about 1 fold higher than FW of shoots obtained on S1-2 medium (Table 2). Likewise, the average DW of rosettes was higher for the cultures grown on MS medium and amounted to $0.063 \mathrm{~g}$. The multiplication coefficient of the cultures on the S1-1 medium was higher, and reached 5.24, compared to the S1-2 medium (1.0) (Table 2). The average number of regenerated rosettes did not change significantly with successive passages, only new leaves emerged. On the S1-2 medium, the plant material did not multiply as effectively as on S1-1 throughout the experiment. 
Table 2

Growth parameters and micropropagation efficiency of Pulsatilla turczaninovii microrosettes assessed 4 weeks (S1-1, S1-2) and 6 weeks (S2-1, S2-2, S2-3, S2-4) from the last passage of the culture

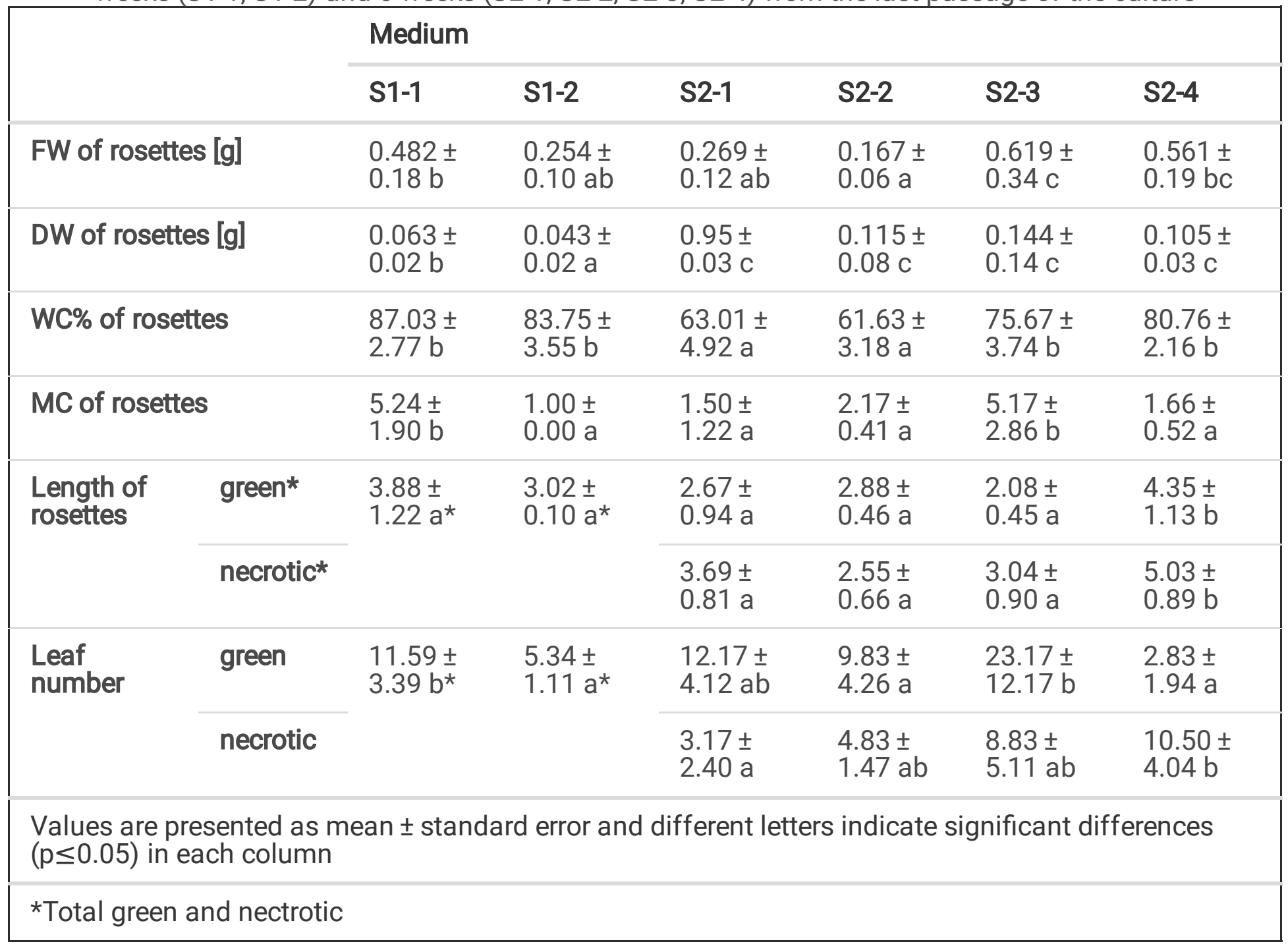

During the second stage of micropropagation, media were diversified in a relation to phytohormone concentration. The shoots multiplied on all tested media, but the best effects were observed on S2-3 where multiplication coefficient amounted to 5.17 (Table 2). On media S2-3 and S2-4 microrosettes achieved the highest FW (Table 2). No statistical differences were observed regarding DW of plants developed. The longest leaves grew on S2-4 medium. On the medium S2-3, rosettes produced the highest number of green leaves, which averaged to 23.17. The highest number of leaf necrotization was recorded on S2-4, amounting to 10.5, and exceeding the number of green leaves developed on the rosettes (2.83).

During 8 weeks of rooting phase, rosettes regenerated roots more efficiently on the tested media S3-2, S33 and S3-4, in comparison with S3-1 medium (Table 3). The highest rooting efficiency was noted on media S3-3 and S3-4, supplemented with ACC and it was $19.9 \%$ and $15.5 \%$, respectively (Fig. 4D, Table 3). Irrespectively of the rooting medium, the average number and average length of adventitious roots was similar (Table 3). 
Table 3

Effect of induction media on rooting parameters of Pulsatilla turczaninovii microrosettes after 6 weeks of culture calculated on a basis of rooted explants

\begin{tabular}{|lllll|}
\hline Medium & Treatment & $\begin{array}{l}\text { Rooting } \\
\text { efficiency [\%] }\end{array}$ & $\begin{array}{l}\text { Average number of roots } \\
\text { per explant* }\end{array}$ & $\begin{array}{l}\text { Average root } \\
\text { length [cm] }\end{array}$ \\
\hline S3-1 & no PGR & $0 \pm 0 \mathrm{a}$ & $0 \pm 0 \mathrm{a}$ & $0 \pm 0 \mathrm{a}$ \\
\hline S3-2 & IBA $\left(1.0 \mathrm{mg} \mathrm{L}^{-1}\right)$ & $6.66 \pm 3.22 \mathrm{~b}$ & $3.0 \pm 1.0 \mathrm{~b}$ & $0.70 \pm 0.1 \mathrm{~b}$ \\
\hline S3-3 & ACC $\left(1.0 \mathrm{mg} \mathrm{L}^{-1}\right)$ & $19.98 \pm 4.56 \mathrm{c}$ & $1.78 \pm 0.83 \mathrm{~b}$ & $0.48 \pm 0.13 \mathrm{~b}$ \\
\hline S3-4 & $\begin{array}{l}\text { IBA }\left(1.0 \mathrm{mg} \mathrm{L}^{-1}\right)+\text { ACC } \\
\left(1.0 \mathrm{mg} \mathrm{L}^{-1}\right)\end{array}$ & $15.54 \pm 8.29 \mathrm{c}$ & $1.83 \pm 0.75 \mathrm{~b}$ & $0.57 \pm 0.08 \mathrm{~b}$ \\
\hline
\end{tabular}

Values are presented as mean \pm standard error and different letters indicate significant differences $(p \leq 0.05)$ in each column

\section{Changes in biochemical parameters during rooting induction phase}

The initial concentration of total phenolic compounds (TPC), determined at the beginning of rooting induction phase (day 0 ) on each rooting medium was the same (Fig. 5A). On control medium S3-1 the amounts of TPC did not changed throughout the entire induction phase that lasted 7 days. TPC increased significantly on the 2nd day on media S3-2, S3-3 and S3-4, with the highest concentration determined for medium S3-2. On the 7th day of induction phase, further increase of TPC occurred in all phytohormoneenriched media. Again the highest TPC content was the highest on S3-2 medium, where it increased 3fold in comparison with S3-1 medium reaching $11.17 \mathrm{mg} \mathrm{g}^{-1} \mathrm{FW}$. On media S3-3 and S3-4 microrosettes accumulated similar amounts of TPC, amounting to $7.26 \mathrm{mg} \mathrm{g}^{-1} \mathrm{FW}-\mathrm{S} 3-3$ and $7.89 \mathrm{mg} \mathrm{g}^{-1} \mathrm{FW}-\mathrm{S} 3-4$ (Fig. 5A).

Total content of soluble sugars (TSS) significantly increased between the beginning (day 0) and the 2nd day of rooting induction phase in the media containing phytohormones: S3-2, S3-3 and S3-4. In the same period on medium S3-1 TSS content remained unchanged (Fig. 5B). TSS level rapidly rose on media S3-3 and S3-4, however the highest concentration on medium S3-3 was determined on the 2nd day, while on medium S3-4 on the 7th day of rooting induction. On hormone-free S3-1 medium TSS increased slightly, but significantly, on the 7th day.

Peroxidase activity (POD) increased significantly on 2nd day of cultivation on rooting medium, irrespectively of its composition (Fig. 5C). Enzyme activity on the 7th day on media S3-3 and S3-4 remained as high as on the 2 nd day. In turn, on media S3-1 and S3-2 POD activity was slightly lower at the end of rooting induction phase than on its 2 nd day. However, it was still higher than at the beginning of rooting experiment. Considering the changes observed on the 2nd day, POD activity was higher in microrosettes from media S3-1 and S3-2 than on media S3-3 and S3-4. On the 7th day enzyme activity was the same, irrespectively of medium type (Fig. 5C). 
Significant correlations were found between some rooting parameters and the levels of biomarkers (Table 4). Rooting efficiency was positively correlated with TSS content, and negatively with POD activity, determined in both terms of root induction phase. Correlation coefficients were particularly strong when these compounds were analyzed on the second day $(R=0.974$ and $R=-0.834$ for TSS and POD, respectively) in comparison with the seventh day (Table 4). TSS content on the 7th day was positively correlated also with root length $(R=0.863)$ and root number $(0.730)$. These two rooting parameters were positively correlated with TPC contents determined in both terms (Table 4), as well as with each other (R $=0.975$ ). In case of biomarkers we noted that on the second day TSS content was negatively correlated with POD activity.

Table 4

Correlation matrix of biochemical markers: the content of total phenolics (TPC), total soluble sugars (TSS) and peroxidase activity (POD), determined after 2 and 7 days of rooting induction, and rooting parameters (R\%- rooting efficiency, $R \mathrm{~L}$ root length, Root no./ex - number of roots per rooted explant)

\begin{tabular}{|c|c|c|c|c|c|c|}
\hline & TPC & TSS & POD & $\mathrm{R} \%$ & R L & Root no./ex \\
\hline & \multicolumn{6}{|c|}{2 days of rooting induction } \\
\hline TPC & \multicolumn{6}{|l|}{1.000} \\
\hline TSS & 0.371 & \multicolumn{5}{|l|}{1.000} \\
\hline POD & -0.053 & -0.932 & \multicolumn{4}{|l|}{1.000} \\
\hline $\mathrm{R} \%$ & 0.461 & 0.974 & -0.834 & \multicolumn{3}{|l|}{1.000} \\
\hline R L & 0.897 & 0.401 & -0.049 & 0.568 & \multicolumn{2}{|l|}{1.000} \\
\hline \multirow[t]{2}{*}{ Root no./ex } & 0.813 & 0.241 & 0.126 & 0.430 & 0.975 & 1.000 \\
\hline & \multicolumn{6}{|c|}{7 days of rooting induction } \\
\hline TPC & \multicolumn{6}{|l|}{1.000} \\
\hline TSS & 0.630 & \multicolumn{5}{|l|}{1.000} \\
\hline POD & 0.379 & -0.365 & \multicolumn{4}{|l|}{1.000} \\
\hline $\mathrm{R} \%$ & 0.252 & 0.782 & -0.780 & \multicolumn{3}{|l|}{1.000} \\
\hline R L & 0.930 & 0.863 & 0.031 & 0.568 & \multicolumn{2}{|l|}{1.000} \\
\hline Root no./ex & 0.982 & 0.730 & 0.198 & 0.430 & 0.975 & 1.000 \\
\hline
\end{tabular}

\section{Discussion}

In the presented study, we dealt with difficult plant material. The starting material for the experimental work was taken from a locally grown population. Some Pulsatilla species are confined to temperate areas of the Northern hemisphere, and those prefer dry grassland habitats as for example European lowland 
populations of $P$. pratensis (Bochenková et al. 2012, 2015) or $P$. grandis (Bochenková et al. 2017). Tissue culture of Pulsatilla patens was initiated from seeds collected from naturally grown population by Priede and Klavina (2011) and the same methodological approach was chosen in the case of $P$. turczninovii. The habitats of Asiatic species such as $P$. turczaninovii, $P$. flavescens or $P$. bungeana exist in NorthMongolian forest-steppe (Dulamsuren et al. 2005a,b; Gantuya et al. 2019; Gunin et al. 2020) and AltaiSayan mountain steppes (Namzalov et al. 2018; Shadgar and Yadamsuren 2017). The habitat of $P$. turczaninovii was also ascertained in the alpine meadows in the mountainous area over $1000 \mathrm{~m}$ above sea level (Ermakow et al. 2014). Lake Baikal, has been declared a UNESCO World Heritage Site and therefore it has been explored for many years. The guide to plants of Buriatia was given by Anenkhonov et al. (2001). Next, among many others, Anenkhonov and Chytrý (1998), and Namzalov et al. (2018) investigated the vegetation of Baikal's region. It turns out to be an unstable area due to anthropogenic causes (Popovicheva et al. 2021). Pulsatilla turczaninovii is one of the important species of this unique flora, and it should be preserved as a valuable resource for future generations. Improving propagation, cultivation and seed storage conditions give an ideal opportunity to maintain plant biodiversity, which is often the case of species described for its medicinal properties (Abeli et al. 2020;Grigoriadou et al. 2011, 2019; Danova et al. 2009). To the important works in tissue cultures of Asiatic Pulsatilla species should be included those by Jin et al. (2007) and Lin et al (2011) regarding Pulsatilla koreana because it produces different valuable bioactive compounds. Lin et al. (2011) obtained the regeneration of this species via organogenesis or somatic embryogenesis (SE). In the case of our material the protocol to obtain rooted plants through organogenesis was achieved, but SE still needs to be developed for $P$. turczninovii.

Our paper presents generative (by seed sowing) and vegetative micro-reproduction of $P$. turczaninovii. The germination, ex situ development of this species, and its efficient in vitro multiplication were assessed. The viable seedlings were obtained from sown achenes. The germination percentage of about 55 was achieved, which is an acceptable value, considering the long storage period of the seeds. Seed germination is one of the difficult-to measure plant reproductive traits, but it is a trait often used in research (Peti et al. 2017). In the short-lived plant species Ensslin et al. (2017) found that seed dormancy could be highly variable. Under natural conditions, the tested species reproduces mainly from seeds. Some seeds germinate in the fall and the rest in the spring of the following year. In the winter the seeds require a freezing period under the snow cover (Wang and Bartholomew 2001). Kozłowski (1959), based on the research of $P$. pratensis, proved that with the storage of fruit, seeds lose their value, and germination decreases by about $30 \%$. While in the case of $P$. patens the percentage of seed germination of freshly harvested fruit varied from $80-98 \%$, and after a few months of storage it dropped to $60 \%$ (Priede and Klavina 2011). These data suggest that the seed material should be sown immediately after harvest. In our experiment, the incised achenes were sown some months after the harvest date, which may be the reason for their relatively low emergence. The results obtained for $P$. turczaninovii correspond to the percentage of $P$. patens seeds germinating after several months of storage (Priede and Klavina 2011). Yuan et al. (2019) conducted extensive research on the germination of $P$. turczaninovii and breaking of seed dormancy. Visually full seeds upon harvest germinated in $52.6 \%$, but seeds that were dry 
stored for 44 weeks had lower germination rate - from $26.3-29.7 \%$. Our results were similar to the germination of seeds after harvest (Yuan et al. 2019), even though they were sown after a few months from the moment of harvesting.

Radziul (2015), cultivating this species in the climatic conditions of Poland, stated that its frost resistance is sufficient, which we also confirmed, because plant wintering both in pots and in the ground survived the winter (Table 1). The proper selection of the site is extremely important, because the soil should be well drained and not too moist, preferably gravel and rocky. The rock garden in which we grew plants has too heavy soil, because in the third season some of the plant roots were rotten. The reason was probably the large biomass, which accumulated moisture during unusually rainy and wet winter. Therefore, in our conditions, the substrate for the cultivation of $P$. turczaninovii should be very permeable. In third cultivation season all plants abundantly produced flowers.

There is a number of reports indicating that medium IAA supplementation gave satisfactory growth response manifested by the highest number of shoots and high rooting rate (Victorio et al. 2012). For the species $P$. vulgaris and $P$. grandis, IAA was also used in concentrations ranging from 0.1 to $0.5 \mathrm{mg} \mathrm{L}^{-1}$ but in combination with BAP (Šaulienè and Brinkyte 2009). Here, the best effects of shoot multiplication induction were obtained on MS medium with the addition of $0.1 \mathrm{mg} \mathrm{L}^{-1} \mathrm{IAA}$ and $0.2 \mathrm{mg} \mathrm{L}^{-1}$ BAP. Priede and Klavina (2011) on media with the addition benzyladenine or topolin at concentrations of 0.25 and 0.5 $\mathrm{mg} \mathrm{L}^{-1}$ obtained 3-fold multiplication rate, and $5 \mathrm{mg} \mathrm{L}^{-1}$ kinetin resulted in 2-fold shoot number. On our media with the addition of $2 \mathrm{IP}$ and IAA, we have obtained a multiplication ratio exceeding 5.0. During the studies on shoot propagation of $P$. koreana, a constant addition of $0.05 \mathrm{mg} \mathrm{L}^{-1}$ IAA was used along with variable concentrations of zeatin and $B A$. The best effects were obtained for $1.5 \mathrm{mg} \mathrm{L}^{-1}$ zeatin, obtaining a propagation coefficient as much as 21.3 and for $1.0 \mathrm{mg} \mathrm{L}^{-1} \mathrm{BA}-7.1$ (Lin et al. 2011). Average length of shoot for this species was usually longer than average length what we observed for $P$. turczaninovii. Until now, research has been conducted on the in vitro cultures of few Pulsatilla species (Jin et al. 2007, Danova et al. 2009, Lin et al. 2011, Priede and Klavina 2011). There are no available literature data on in vitro cultures of $P$. turczaninovii. It is therefore the first study in which the possibilities of reproduction of this species under in vitro cultures was elaborated. High multiplication coefficient, higher fresh weight, the highest number of green leaves mean that the medium with $2.5 \mathrm{mg} \mathrm{L}^{-1} 2 \mathrm{iP}+1 \mathrm{mg} \mathrm{L}^{-1}$ IAA should be considered the best for the propagation of $P$. turczaninovii shoots.

The formation of adventitious roots on microcuttings is a critical step to obtain plantlets ready to be acclimatized to ex vitro conditions. We proved that during rooting of $P$. turczaninovii microrosettes the rooting efficiency was higher on media with the $1.0 \mathrm{mg} \mathrm{L}^{-1}$ of ethylene precursor ACC in comparison with medium supplemented with $1.0 \mathrm{mg} \mathrm{L}^{-1}$ of indole-3-butyric acid (IBA), and rooting percentage was amounted to 15.5-19.98. Arigita et al. (2003) for in vitro culture of Actinidia also found that supplementation of rooting medium with low ACC levels proved to be beneficial for adventitious root induction. Rooting was also enhanced by ACC addition in the cultures of apple (Ma et al. 1998) and peach (Park et al. 2017), it was attributed to interactions between ethylene and auxin levels in the 
regulation of adventitious rooting (Velocia et al. 2016, Park et al. 2017). The Altamura research group working with $A$. thaliana (Velocia et al. 2016; Fattorini et al. 2018) found that ACC at $0.1 \mu \mathrm{M}$ enhanced formation of adventitious roots when combined with IBA $(10 \mu \mathrm{M})$, but reduced it when applied alone, while in our study, both variants turned out to be beneficial in rooting induction. Sediva (2012) reported that incision on the base of shoots of $P$. vernalis had beneficial effect on root induction. Moreover application of auxin during in vitro rhizogenesis affected later acclimatization of plantlets. However, achieved rooting efficiency in culture, reaching $15-20 \%$, is not satisfactory for more widespread production of $P$. turczaninovii plants. Rooting difficulties limit the rate of vegetative propagation of the species, and also are a serious obstacle in its commercial propagation. In order to improve this stage of plantlet development, an insight into rooting physiology of difficult-to-root species is necessary (Wiszniewska et al. 2016). The changes in accumulation of phenolic compounds and carbohydrates, as well as in activity of peroxidase are often associated with rooting ability and root formation at the earliest stages of rhizogenesis (de Klerk et al. 1999, Günes 2000, Denaxa et al. 2012, 2020). Monitoring of their fluctuations may allow choosing the most optimal time for plantlet transfer to elongation medium, adjusted to altered auxin requirements of cultured plantlets (de Klerk et al. 1999, Wiszniewska et al. 2016). We observed that in P. turczaninovii rooting parameters improved when accumulation of soluble sugars was enhanced, similarly to results reported for carnation cuttings (Agulló-Antónet al. 2011). The content of soluble sugars on the 2nd day of root induction phase was positively correlated with rooting efficiency, and on the 7th with all studied rooting characteristics. Involvement of carbohydrates, particularly soluble sugars, in adventitious rooting process is usually related to their role as a carbon and energy source (Megre et al. 2011, Otiende et al. 2017). In this respect TSS can be considered the most impactful biomarker in studied species, and factors stimulating TSS synthesis could potentially enhance its rooting ability. Rooting was also promoted when moderate level of phenolic compounds was maintained, since at low (S3-1) and high (S3-2) TPC concentrations root formation was strongly limited. In P. turczaninovii this parameter was positively correlated with root length and number. It may reflect influence of TPC on formation of root meristematic centers (Druege et al. 2000). Surprisingly, our study revealed that POD activity was negatively correlated with rooting efficiency in $P$. turczaninovii culture, and did not correspond with root length and number. However, its suitability as a rooting biomarker was assessed mainly in studies on woody plants (Günes et al. 2000, Merge et al. 2011). Analyses of cellular and cell-wall bound POD fractions could facilitate verification of POD role in $P$. turczaninovii adventitious rooting in the future. It is postulated that the highest POD activity occurs at the end of root initiation phase, and prolonged exposure to exogenous auxin may inhibit further root development (Gaspar et al. 1992, Li et al. 2009). In our experiment observed decline in POD activity at 7th day on media S3-1 and S3-2 may suggest that the optimal time for transfer at hormone-free medium was overdue. Application of ACC could delay initiation phase and therefore the root formation was not suppressed. As noted above, the higher rootability occurred in media containing an ethylene precursor, alone or in a combination with auxin. It may be attributed to ethylene potential to control distribution of root initiation regions (Rasmussen et al. 2017). To our knowledge these are first data related to biochemical background of adventitious rooting in Pulsatilla species. 


\section{Conclusions}

We herewith confirm the possibility to obtain $P$. turczaninovii plant tissue bank under in vitro conditions which is sine qua non condition to create ex situ collection. The propagation protocol under in vitro conditions was achieved, among others using a modified MS medium enriched with 2iP and IAA. We ascertained that the addition of $1.0 \mathrm{mg} \mathrm{L}^{-1} \mathrm{ACC}$ and $1.0 \mathrm{mg} \mathrm{L}^{-1}$ IBA is beneficial for rooting of regenerated micro-rosettes. Among all determined parameters, accumulation of soluble sugars exerted the most significant impact on efficiency of rhizogenesis, as well as some characteristics of regenerated adventitious roots. We also conclude that successful cultivation of Pulsatilla turczaninovii can be carried out in the climatic conditions of Poland. However, it is necessary to properly select the site and appropriately prepare the substrate for the optimal growth of regenerated plants. Owing to developed micropropagation protocol it is possible to produce affordable material useful for breeding schemes or plain horticultural production. Thus we managed contribute to the Pulsatilla protection program.

\section{Abbreviations}

ACC-1-aminocyclopropane-1-carboxylic acid

ANOVA - Analysis of variance

IAA - Indole-3-acetic acid

IBA - Indole-3-butyric acid

MS - Murashige and Skoog Medium

POD - Peroxidase (EC 1.11.1.7)

TPC - Total phenolic compounds

TSS - Total soluble sugars

WPM - Woody Plant Medium

\section{Declarations}

\section{Authors Contributions:}

Conceptualization: EH-F, AW, DK; Methodology: E.H-F, AW, DK, AK; Seed Germination and Plant Culture: DK, EM, EH-F; Biochemical analyses: AK; Statistical analyses AK, AW; Writing - Original Draft Preparation: EHF, DK; AW; Writing - Review \& Editing: EH-F; AW, AK; EM; Supervision EH-F; Funding Acquisition: EH-F. This research was supported by Ministry of Science and Higher Education of the Republic of Poland in the form of subsidy No. 2016-2020-0012-D011. 


\section{Acknowledgments}

We would like express our gratitude to His Magnificence Rector of University of Agriculture in Krakow for co-financing the trip of some participants of Interdepartmental Phytogeography Student's Scientific Circle with their tutors from research and teaching staff to the M. K. Ammosov North-Eastern Federal University and the Botanic Garden of the Irkutsk State University, Russia and their scientific expedition to the area of Lake Baikal, as well as the possibility of visiting in Baikal Museum ITS SB RAS. The statutory activity of Department of Botany, Physiology and Plant Protection, University of Agriculture in Kraków as laboratory research, field experiments and publication of results were financed by the Ministry of Science and Higher Education of the Republic of Poland.

\section{References}

Abeli T, Dalrymple S, Godefroid S, Mondoni A, Müller JV., Rossi G, Orsenigo S (2020) Ex situ collections and their potential for the restoration of extinct plants. Conserv Biol 34(2): 303-313. https://doi.org. 10.1111/cobi.13391

Agulló-Antón MÁ, Sánchez-Bravo J, Acosta M, Druege U (2011) Auxins or sugars: what makes the difference in the adventitious rooting of stored carnation cuttings? J Plant Growth Regul 30: 100-113. https://doi.org/10.1017/s00344-010-9174-8

Anenkhonov O, Chytrŷ M (1998) Syntaxonomy of vegetation of the Svyatoi Nos penisula, Lake Baikal. 2. Forests and krummholz in comparison with other regions of the Nothern Buriatia. Folia Geobot 33:31-75. https://doi.org./10.1007/BF02914929

Anenkhonov O, Pykhalova TD, Osipov KI, Cekulich IR, Badmaeva NK, Namzalov BB, Krivobokov LV, Munkueva MC, Sutkin AV, Tubshinova DB,Tubanova DY (2001). Opredelitel' rastenii Buryatii Ulan- Ude, $672 \mathrm{pp}$.

Antoń S, Kamińska M (2015) Comparative floral spur anatomy and nectar secretion in four representatives of Ranunculaceae. Protoplasma 252: 1587-1601. https://doi.org/10.1007/s00709-0150794-5

Arigita L, Sánchez Tamés R, González A. (2003) 1-Methylcyclopropene and ethylene as regulators of in vitro organogenesis in kiwi explants. Plant Growth Reg 40: 59-64.

https://doi.org/10.1023/A:102307031422

Blainski A, Lopes GC, De Mello JCP (2013) Application and Analysis of the Folin Ciocalteu Method for the Determination of the Total Phenolic Content from Limonium brasilense L. Molecules 18: 6852-6865. https://doi.org/10.3390/molecules 18066852

Bochenková M., Hejcman M., Karlīk P (2012) Effect of plant community on recruitment of Pulsatilla pratensis in dry grassland. Sci Agric Bohem 4: 217-133. https://doi.org./10.7160/sab.2012.430402 
Bochenková M, Karlīk P, Hejcman M (2015) Effect of nitrogen, appendage removal, locality and year on seed germination of the endangered dry grassland species Pulsatilla pratensis (L.) Mill. Prop Ornam Plants 15(4): 154-162

Bochenková M, Karlīk P, Hejcman M, Jiras P (2017) Does seed modification and nitrogen addition affect seed germination of Pulsatilla grandis? Sci Agric Bohem 48(4): 106-223. https://doi.org/10.1515/sab2017- 0029

da Silva HA, Parizotto AV, Moreira FC, Marques RM, Reis B, Bonato CM (2012) The effect of high dilutions of Pulsatilla nigricans on the vigour of soybean seeds subjected to accelerated ageing. Act Sci Agronomy 34(2): 201-206. https:doi.org/10.4025/actascieagron.v34i2.130043

Danova K, Bertoli A., Pistelli L., Dimitrov D., Pistelli L (2009) In vitro culture of Balkan endemic and rare Pulsatilla species for conservational purposes and secondary metabolites production. Bot Ser 33(2): 157-162

De Klerk G-J, van der Krieken W, De Jong JC (1999) The formation of adventitious roots: new concepts, new possibilities. In Vitro Cell Dev Biol - Plant 35: 189-199. https://doi.org/10.1007/s11627-999-0076-Z

Denaxa N K, Vemmos SN, Roussos PA (2012). The role of endogenous carbohydrates and seasonal variation in rooting ability of cuttings of an easy and a hard to root olive cultivars (Olea europaea L.). Sci Hort 143: 19-28. https://doi.org/10.1016/j.scienta.2012.05.026

Denaxa, NK, Roussos PA, Vemmos SN (2020). Assigning a Role to the Endogenous Phenolic Compounds on Adventitious Root Formation of Olive Stem Cuttings. J Plant Growth Regul 39: 411-421. https://doi.org/10.1007/s030344-019-09991-0

Deng X, Ye Y, Han L, Jiao Y, Han S (2019) Chemical constituent and chemotaxonomic study on the root of Anemone vitifolia Buch. Ham. Bioch System Ecol 87: 103955. https://doi.org/10.1016/j.bse.2019.103955

Di Musciano M, Carranza ML, Frate L, Di Cecco V, Di Martino L, Fratolli R, Stanisci A (2018) Distribution of plant species and dispersal traits along environmental gradients in Central Mediterranean Summits.

Diversity 10: 58. https://doi.org/ 10.3390/d10030058

Druege U, Zerche S, Kadner, R, Ernst, M (2000). Relation between nitrogen status, carbohydrate distribution and subsequent rooting of chrysanthemum cuttings as affected by pre-harvest nitrogen supply and cold-storage. Ann Bot 85(5): 687-701. https://doi.org/10.1006/anbo.2000.1132

Dulamsuren Ch, Hauck M, Mühlenberg M (2005a) Ground vegetation in the Mongolian taiga forest-steppe ecotone does not evidence for the human origin of grasslands. Appl Veg Sci 8:149-154

Dulamsuren Ch, Welk E, Jäger EJ, Hauck M (2005b) Range-habitat relationships of vascular plant species at the taiga-forest steppe borderline in the western Khentey Mountains, northern Mongolia. Flora 200: 375-379. doi: 10.1016/j.flora.2005.02.002 
Ensslin A, Van de Vyver A, Vanderborght T, Godefroid S (2017) Ex situ cultivation entails high risk of seed dormancy loss on short-lived wild plant species. J Appl Ecol 55:1145-1154.

https://doi.org/10.1111/1365-2664.13057

Ermakow N, Larionov A, Polyakova M, Pestunov I, Didukh Y (2014) Diversity and spatial structure of cryophytic steppes of the Minusinskaya intermountain basin in Southern Siberia (Russia) Tuxenia 34: 431. doi: $10.14471 / 2014$

Fattorini L, Hause B, .Gutierrez L, Veloccia A, Della Rovere F, Piacentini D, Falasca G, Altamura MM (2018) Jasmonate promotes auxin-induced adventitious rooting in dark-grown Arabidopsis thaliana seedlings and thin stem layers by cross-talk with ethylene signaling and modulation of xylogenesis. BMC Plant Biology 18: 182. https://doi.org/10.1186/s12870-018-1392-4

Gantuya B, Avar Á, Babai D, Molnár ZS (2019) "A herder's duty to think": landscape partitioning and folk habitats of Mongolian herders in a mountain forest steppe (Khuvusgul-Murun region) J Ethnobiol Ethnomed 15:54. https://doi.org/10.1186/s13002-019-0328-x

Gaspar T, Kevers C, Hausman J, Berthon Jy, Ripetti V. (1992). Practical uses of peroxidase activity as a predictive marker of rooting performance of micropropagated shoots. Agronomie, EDP Sciences 12 (10): 757-765

Grigoriadou K, Krigas N, Maloupa E (2011) GIS-facilitated in vitro propagation and ex situ conservation of Achilea occulta. Plant Cell Tiss Organ Cult 107: 531-540. https://doi.org/10.1007/s11240-011-0004-x

Grigoriadou K, Krigas N, Sarropolou V, Papanastasi K, Tsoktourdis G, Maloupa E (2019) In vitro of medicinal and aromatic plants: the case of selected Greek species with conservation priority. In Vitro Cell Dev Biol Plant 55: 635-646. https://doi.org/10.1007/s11627/-019-10014-6

Günes T (2000) Peroxidase and IAA-oxidase activities during rooting in cuttings of three poplar species. Turk J Bot 24: 97-101

Gunin PD, Bazha SN, Miklyaeva IM, Karimova TY, Petukhow IA, Andreev AV, Bogdanov EA, Tsyrempilov EG (2020) Practice of geobotanical Indication of forest growth conditions in the steppe and wooded steppe ecotone in Central Mongolia. J Ecol Engin 21(2) : 10-21. http://doi.org/10.12911/22998993/116340

Hanus-Fajerska E, Ciarkowska K, Muszynska E (2019) Long-term field study on stabilization of contaminated wastes by growing clonally reproduced Silene vulgaris calamine ecotype. Plant Soil 439: 431-445. https://doi.org/10.1007/s11104-019-04043-8

Hao DC, Xiao PG, Ma HY, Peng Y, He CN (2015) Mining chemodiversity from biodiversity: pharmacophylogeny of medicinal plants of Ranunculaceae. Chinese J Nat Med 13(7): 507-520

Jiang SQ, Zhang YB, Xiao M, Jiang L, Luo D, Niu QW, Li YL, Zhang XT, Wang GC (2017) Cycloartane triterpenoid saponins from the herb of Thalictrum fortunei. Carbohydrate Res 445: 1-6 
Jin JS, Hun JJ, Soo YE, Eui CY(2007) Plant regeneration and adventitious root segments of Pulsatilla koreana Nakai. J Plant Biotechnol 34(2): 153-159. https://doi.org/10.5010/JPB.2007.34.2.153

Kaligaričet M, Śkornik S, Ivančič A, Rebeuŝek F, Senčič L(2006) Germination and survival of endangered Pulsatilla grandis (Ranunculaceae) after artificial seeding, as affected by various disturbances. Israel $\mathrm{J}$ Plant Sci 54(1): 9-17

Kozłowski J (1959) Attempts to grow pasque-flower as a medicinal plant (In Polish) Wiad Bot III(2): 121-123

Łaska G, Sienkiewicz A, Stocki M, Zjawiony JK, Shrama V, Bajguz A., Piotrowska-Niczyporuk A, Jacob M, Khan S (2019) Phytochemical screening of Pulsatilla species and investigation of their biological activities. Acta Soc Bot Pol 88(1): 3613. https://doi.org/10.5586/asbp.3613

Łaska G., Sienkiewicz A (2019) Antifungal activity of rhizome extracts of Pulsatilla vulgaris against Candida glabrata. Eur J Biol Res 9(2): 93-103. http://dx.doi.org/10.5281/zendo.3228890

Li SW, Xue L, Xu S, Feng, H, An L (2009). Mediators, genes and signaling in adventitious rooting. Bot Rev 75(2), 230-247

Lin GZ, ZhaoXM, Hong SK, Lian YJ (2011) Somatic embryogenesis and shoot organogenesis in the medicinal plant Pulsatilla koreana Nakai. Plant Cell Tiss Organ Cult 106: 93-103. https:doi.org/ 10.1007/s00240-010-9897-z

Lloyd G, Mc Cown B (1980) Commercially-feasible micropropagation of mountain laurel, Kalmia latifolia, by use of shoot tip culture. Comb Proc Int Plant Prop Sic 30: 21-427

Ma JH, Yao JL, Cohen D, Morris B (1998) Ethylene inhibitors enhance in vitro root formation from apple cultures. Plant Cell Rep 17:211-214

Megre D, Dokane K, Kondratovics U (2011). Can changes in starch content and peroxidase activity be used as rooting phase markers for rhododendron leaf bud cuttings? Act Biol Crac Ser Bot 53(1):74-79 DOI: 10.2478/v10182-011-0010-7

Milinarec J, Franjević D, Bočkor L, Besendorfer V (2016) Diverse evolutionary pathways shaped 5s rDNA of species of tribe Anemonae (Ranunculaceae) and reveal phylogenetic signal. Bot J Linn. Soc 182:80-99. https://doi.org./10.1111/boj.12425

http://dx.medra.org/10.14597/infraeco.2015.4.3.098

Murashige T, Skoog F (1962) A revised medium for rapid growth and bioassays with tobacco tissue cultures. Physiol Plant 15: 473-497. https://doi.org./10.1111/j.1399-3054-1962.tb08052.x 
Muszyńska E, Hanus-Fajerska E, Koźmińska A (2018) Differential tolerance to lead and cadmium in micropropagated Gypsophila fastigiata ecotype. Water Air Soil Pollut 229: 42.

https://doi.org/10.1007/s11270-018-3702-8

Namzalov BBT, Zhigzhitzhapova SV, Taisaev TT, Radnaeva LD, Banaeva SC, Namzalov MBT (2018) On the relic phenomena and influence of volcanic rocks on vegetation of mountain steppes in Southern Siberia. Arid Ecosyst 8(2): 111-121

Otiende, M A, Nyabundi J O, Ngamau K, Opala P (2017). Effects of cutting position of rose rootstock cultivars on rooting and its relationship with mineral nutrient content and endogenous carbohydrates. Sci Hort 225: 204-212

Park SH, Elhiti M, Wang H, Xu A, Brown D (2017) Adventitious root formation of in vitro peach shoots is regulated by auxin and ethylene. Sci Hort 226: 250-260. https://doi.org/10.1016/j.scienta.2017.08.05

Peti E, Schellenberger J, Németh G, Málnási CG,Oláh I, Török K, Czóbel Sz, Baktay B (2017) Presentation of the Huseed Wild - A seed weight and germination database of the Pannonian flora - thorough analyzing life forms and social behavior types. App Ecol Environ Res 15(1): 224-244

Philips GC, Garda M (2019) Plant tissue culture media and practices: an overview. In Vitro Cell Dev Biol-Plant 55:242-257 https://doi.org/10.1007/s11627-019-09983-5

Powel Gaines T (1973) Automated Determination of Reducing Sugars, Total Sugars, and Starch in Plant Tissue from One Weighted Sample. J Ass Anal Chem 56(6): 1419-1424.

http://doi.org/10.1093/joac/56.6.1419

Popovicheva O, Molozhnikova E, Nanasov S, Potemkin V, Penner I, Klemasheva M, Marinaite I, Golobokova L, Vratolis S, Eleftheriadis K, Khodzher T (2021) Industrial and wildfire aerosol pollution over heritage Lake Baikal. Journal of Environmental Sciences 107: 49-64.

https://doi.org/10.1016/j.jes.2021.01.011

Priede G, Klavina D (2011) In vitro cultivation and root initiation of the endangered plant Pulsatilla patens. Environ Exp Bot 9:71-74

Putter J (1974) Peroxidases. In: Bergmeyer HV (Ed.) Methods of enzymatic analysis II. Academic Press, New York, pp 685-690

Radziul E. 2015. A collector's guide. Rockeries. Zysk i S-ka Wyd. Poznań, Poland, pp. 499.

Rasmussen A, Hu Y, Depaepe T, Vandenbussche F, Boyer F D, Van Der Straeten D, Geelen, D (2017). Ethylene controls adventitious root initiation sites in Arabidopsis hypocotyls independently of strigolactones. J Plant Growth Reg 36(4), 897-911 
Šaulienè I, Brinkytė E (2009)The impact of phytohormones on pasqueflower (Pulsatilla) regeneration in vitro. Act Biol Universitatis Daugavpiliensis. Vol.9 No.2 pp.249-254 ref.15

Šedivá J (2012): In vitro root formation in Pulsatillavernalis (L.) Mill. Prop Ornam Plants 12: 96-101

Shadgar D, Yadamsuren $O$ (2017) Plant species and vegetation cover of Kherlen Toono Mountain, Mongolia. J Asia-Pac Biodiv: 132-136. http://dx.doi.org/10.1016/j.apb.2016.06.005

Sramkó G, Laczkó L, Volkova PA, Bateman RM, Mlinarec J (2019) Evolutionary history of the Pasqueflowers (Pulsatilla, Ranunculaceae): Molecular, phylogenetics, systematics, and rDNA evolution. Mol Phyl Evol 135: 45-61. https://doi.org./10.1016/j.ympev.2019.02.015

Tamura M (1993) Ranunculaceae. In: K. Kubitzki, J. Rohwer, V. Bittrich (Eds.) Flowering Plants. Dicotyledons. Springer, Berlin, Heidelberg, pp. 563-519. https://doi.org.10.101007978-3-662-02899-5_57

Velocia A, Fattorini L, Della Rovere F, Sofo A, D'Angeli D, Betti C. Falasca G, Altamura MM (2016) Ethylene and auxin interaction in the control of adventitious rooting in Arabidopsis thaliana. J Exp Bot 67(22): 6445-6458. doi:10.1093/jxb/erw415

Victório C.P., Lage C.,L.,S., Sato A. 2012. Tissue culture techniques in the proliferation of shoots and roots of Calendula officinalis. Rev Ciência Agron 43(3): 539-545

Wang WT, Bartholomew B (2001) Pulsatilla Miller (Ranunculaceae). In: Wu CY. and Raven P. (eds.), Flora of China. Sci. Press; Miss. Bot. Gard. Press, pp. 329-333

Weryszko-Chmielewska E, Sulborska A, Żuraw B, Chyzewska R, Sawdis T (2017) Ecological aspects of the floral structure and flowering of Pulsatilla species. Act Agrobot 70(3): 1715. https://doi.org/10.5586/aa.1715

Wiszniewska A, Nowak B, Kołton A, Sitek E, Grabski K, Dziurka M, Tukaj Z (2016). Rooting response of Prunus domestica L. microshoots in the presence of phytoactive medium supplements. Plant Cell Tiss Organ Cult 125(1): 163-176

Xu L, Nie Y, Chen B, Xin X, Yang G, Xu D, Ye L (2020) Effects of fence enclosure on vegetation community characteristics and productivity of a degraded temperate meadow steppe in Northern China. Appl Sci 10: 2952. doi: 10.3390/app10082952

Xu XT, Jin X, Liao WB, Dawuda MM, Li XP, Wang M, Niu LJ, Zhu, YC (2017). Nitric oxide is involved in ethylene-induced adventitious root development in cucumber (Cucumis sativus L.) explants. Sci Hort 215: 65-71. https://doi.org/10.1016/j.scienta.2016.12.006

Yuan T, Wei Q, Bauchan G (2019) Germination of Pulsatilla Seeds as Influenced by Seed Morphology, Moisture and Gibberellin $\left(\mathrm{GA}_{3}\right)$ Treatment, and Detection of Nickel in Seeds. HortSci 54(11):2015- 2023. https://doi.org/10.21273/HORTSCI14056-19 
Zainelabdeen YM, Yan R, Xin X, Yan Y, Ahmed Al, Hou L, Zhang Y (2020) The impact of grazing on the grass composition in temperate grassland. Agronomy 10: 1230.

https://doi.org/10.3390/agronomy 10091230

\section{Figures}

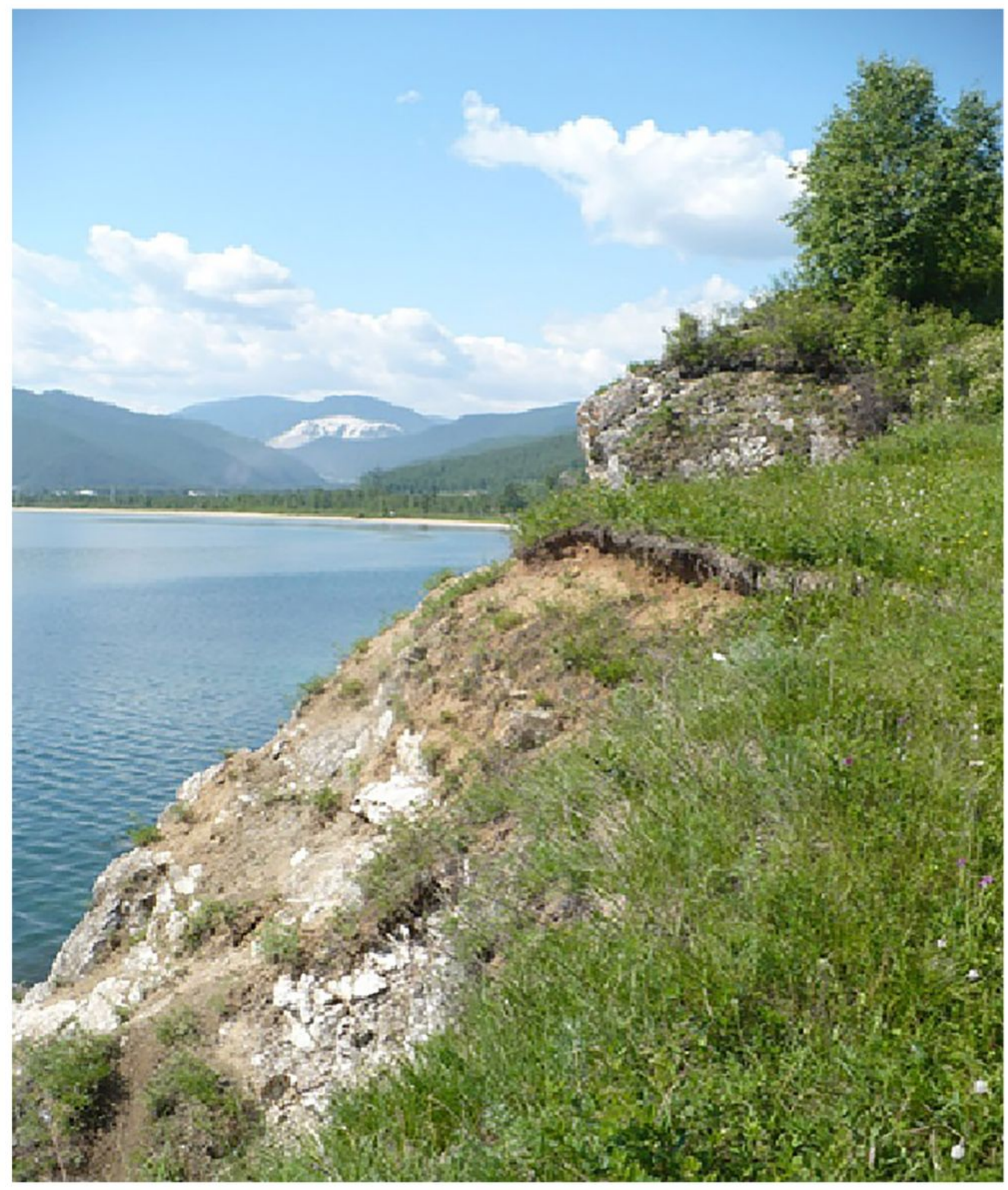

Figure 1 


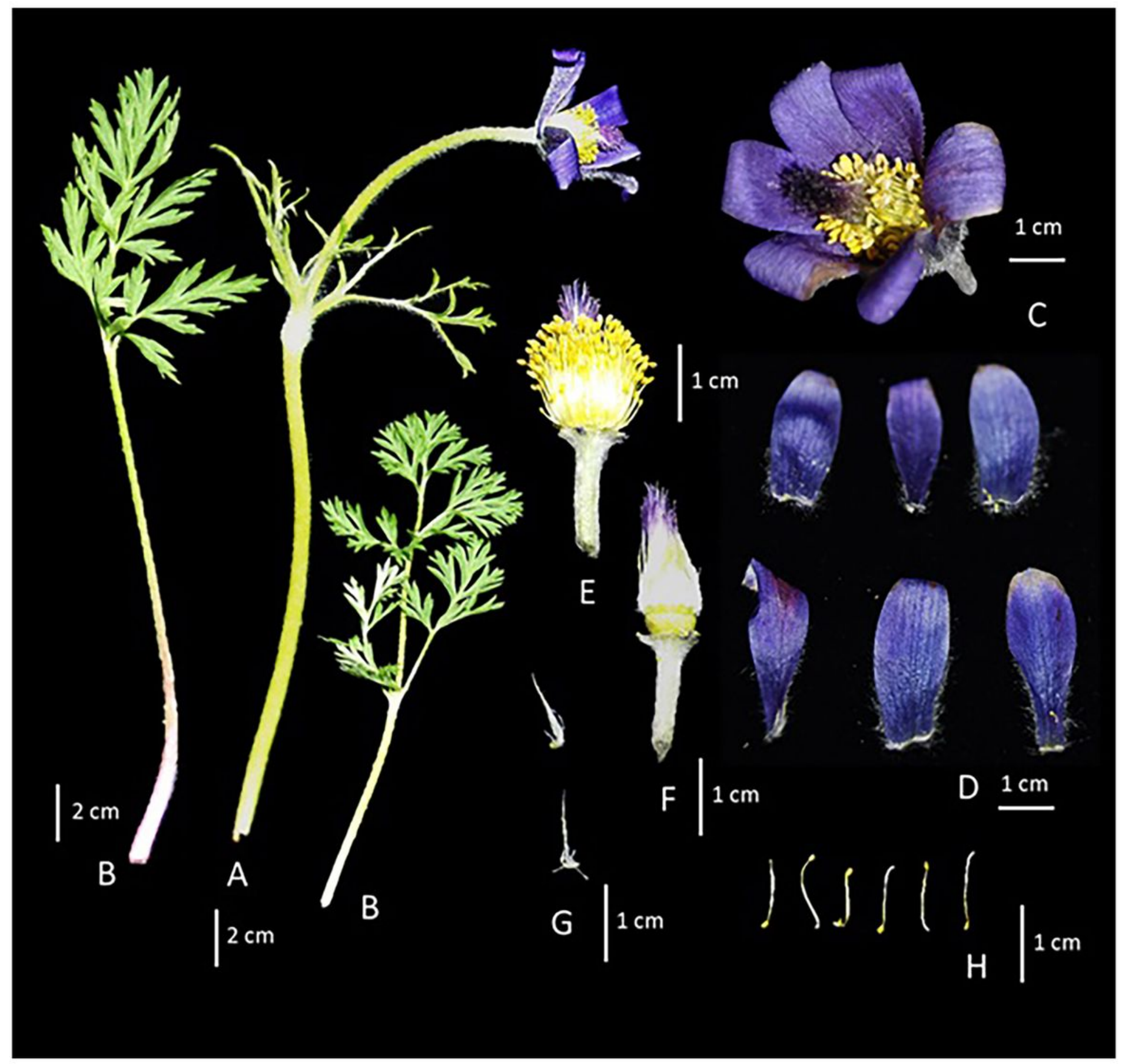

Figure 2

Morphology of Pulsatilla turczaninovii: A - Blooming shoot, B - leaf, C - flower, D - perianth, E receptacle with pistils and stamens, F - receptacle with pistils, G - individual pistil, $\mathrm{H}$ - single stamens 


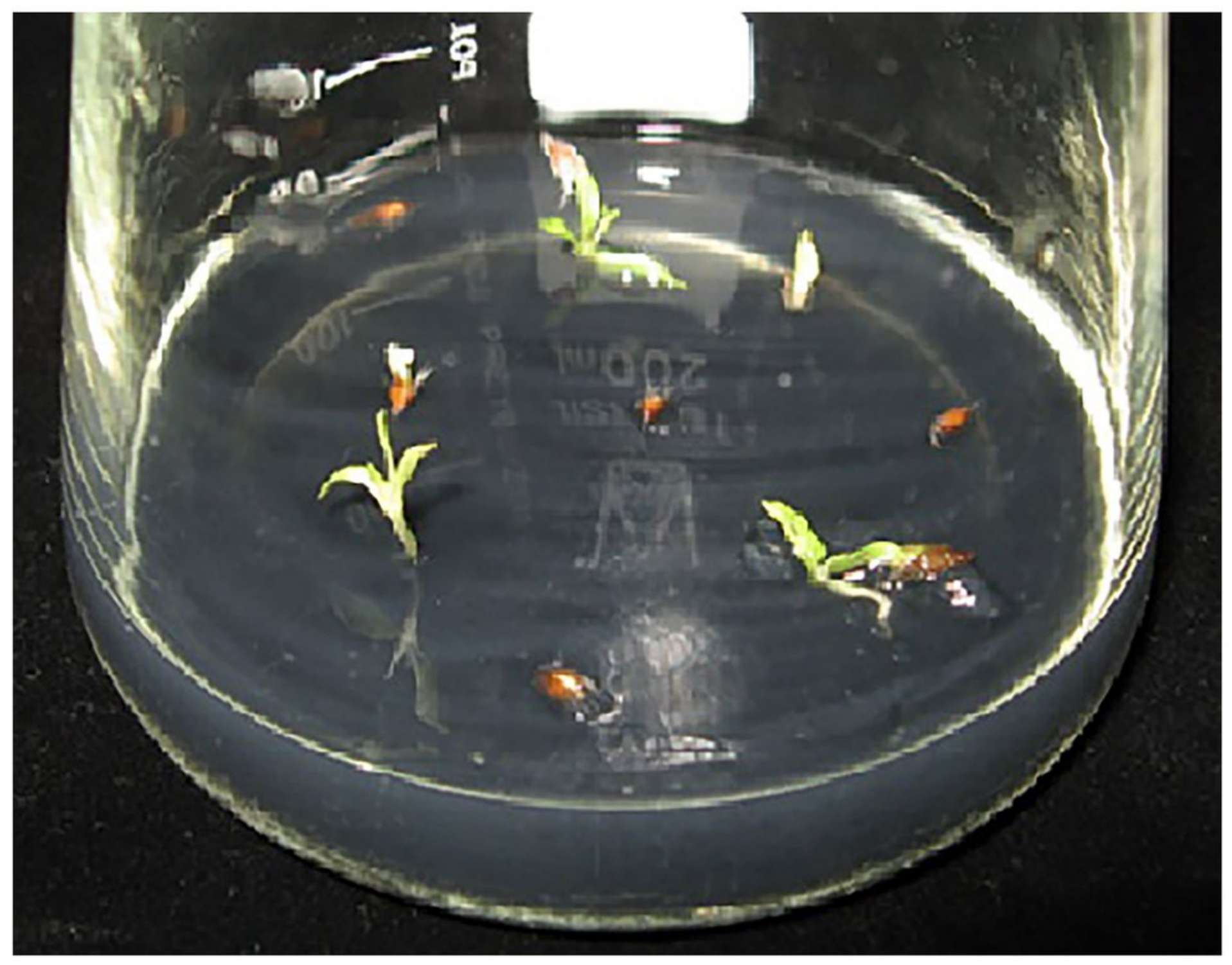

\section{Figure 3}

Aseptic seedlings germinated in vitro on seed germinating medium
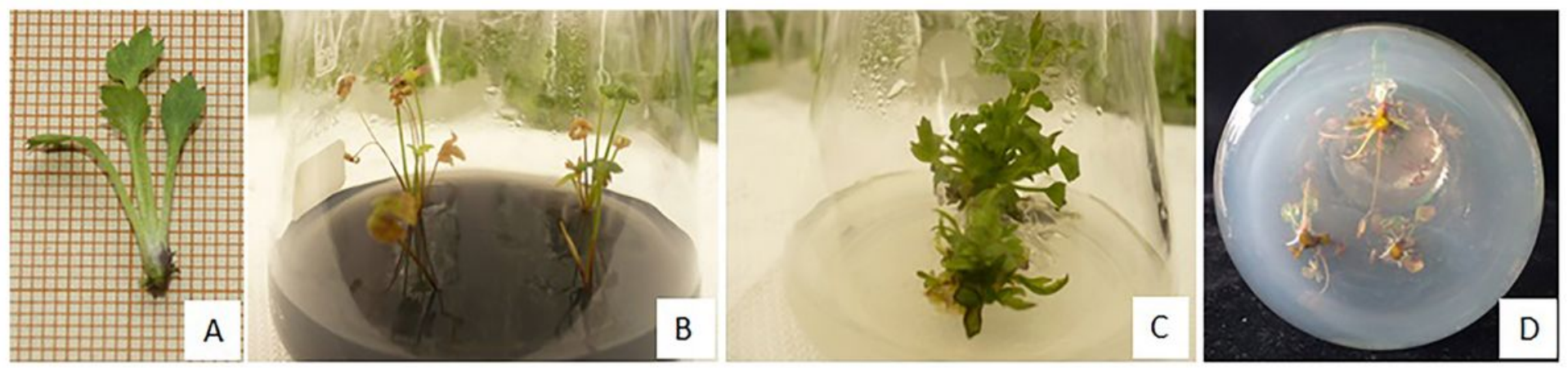

\section{Figure 4}

Development of shoot culture and rooting of microrosettes. A - initial explant, microshoot, B microrossetes on WPM medium, C - microrossetes on MS medium, D - microrossetes during in vitro 
rooting

\section{Image not available with this version}

\section{Figure 5}

The influence of rooting medium (S3-1, S3-2, S3-3, S3-4) on the content of total phenolic compounds (TPC) (a), total soluble sugars (TSS) (b) and peroxidase activity (POD) (c) in Pulsatilla turczaninovii microrosettes before root induction treatment (day 0 ) and after 2 and 7 days culture. 